\title{
EVALUASI PELAKSANAAN \\ PENILAIAN PEMBELAJARAN GEOGRAFI SMA DI KABUPATEN BANTUL
}

\author{
Muhammad Nursa'ban \\ FISE Universitas Negeri Yogyakarta (e-mail: mnsaban@yahoo.com)
}

\begin{abstract}
An Evaluation of the Implementation of the Geography Learning Assessment in Senior High Schools in Bantul Regency. This study aims to evaluate the implementation of geography assessment in senior high schools based on the Regulation by the Minister of the National Education Number 20 Year 2007 about the National Standard of Assessment. This study was an evaluation study employing the Stake's model. The sample, selected by means of the simple random sampling technique, consisted of 56 geography teachers in Years X, XI, and XII of senior high schools. The data were collected using a questionnaire and observation guide and analyzed using the descriptive analysis based on the predetermined criteria. The findings are as follows. 1) The antecedent phase, consisting of assessment principles, is in the very good category. 2) The transaction phase, consisting of assessment techniques, is in the good category. The instruments, mechanisms, and processes of assessment are in the very good category. 3) The outcome phase shows that the assessment of geography learning is in the very good category.
\end{abstract}

Keywords: assessment, geography learning

\section{PENDAHULUAN}

Peraturan Menteri Pendidikan Nasional Nomor 20 Tahun 2007 tentang Standar Penilaian Nasional memberikan patokan dalam penilaian pembelajaran di sekolah. Berdasarkan kebijakan peraturan penilaian tersebut pihak sekolah beserta para guru memiliki kewenangan membuat dan mengembangkan penilaian pembelajaran. Pendidik (guru) adalah tenaga profesional sebagaimana diamanatkan dalam Pasal 39 ayat 2, UU RI No. 20 Tahun 2003. BSNP (2006:16) dinyatakan bahwa guru profesional mampu mengembangkan kegiatan pembelajaran di bidangnya termasuk kemampuan penilaian dalam
Proses Pembelajaran. Penilaian hasil belajar merupakan suatu tindakan dalam memberikan keputusan berdasarkan kriteria tertentu terhadap hasil dari suatu kegiatan atau serangkaian kegiatan (hasil belajar) yang telah dilakukan oleh seseorang atau sekelompok orang dengan menggunakan alat penilaian Menurut Suharsimi Arikunto (2001:3) menilai adalah mengambil suatu keputusan terhadap sesuatu dengan hasil baik atau buruk yang dilakukan secara terencana, terorganisir dan berkesinambungan untuk memberikan pertimbangan atau harga atau nilai tentang proses dan hasil belajar siswa berdasarkan kriteria tertentu untuk memperoleh 
suatukeputusan. Rumusan tersebut bermakna, yakni: (1) bagi siswa, dapat mengetahui sejauhmana telah berhasil mengikuti pelajaran yang diberikan guru; (2) bagi guru, dapat mengetahui tingkat keberhasilan belajar siswanya, ketepatan materi yang diajarkan, dan ketepatan metode yang digunakan; (3) bagi sekolah, dapat mengetahui hasil belajar siswa yang berarti dapat diketahui kondisi belajar yang diciptakan sekolah, tepat tidaknya kurikulum yang digunakan, dan dapat diketahui apakah sekolah sudah memenuhi standar atau belum.

Departemen Pendidikan Nasional (2007:230) memberikan pengertian penilaian adalah proses sistematis meliputi pengumpulan informasi (angka, deskripsi verbal), analisis, interpretasi informasi untuk membuat keputusan. Ditambahkannya yang menjadi ciri-ciri penilaian di kelas adalah (1) belajar tuntas, (2) otentik, (3) berkesinambungan, (4) berdasarkan acuan kriteria /patokan, (5) menggunakan berbagai cara \& alat penilaian. Kegiatan penilaian hasil belajar seperti tertuang dalam Peraturan Menteri Pendidikan Nasional (Permendiknas) Nomor 20 Tahun 2007 bahwa penilaian hasil belajar peserta didik pada jenjang pendidikan dasar dan menengah dilaksanakan berdasarkan standar penilaian pendidikan yang berlaku secara nasional. Berdasarkan peraturan menteri tersebut dijelaskan bahwa pendidik dalam hal ini adalah guru melaksanakan penilaian yang sesuai standar standar nasional pendidikan berkaitan dengan prinsip, teknik, instrumen, dan mekanisme, serta proses penilaian oleh pendidik.
Prinsip-prinsip penilaian dalam pembelajaran yaitu shahih, objektif, adil, terpadu, terbuka, menyeluruh, sistematis, beracuan kriteria, dan akuntabel. Teknik penilaian hasil belajar yang dimaksud dalam ketentuan Permendiknas tersebut berupa tes, observasi, penugasan perseorangan atau kelompok, dan bentuk lain yang sesuai dengan karakteristik kompetensi dan tingkat perkembangan peserta didik. Instrumen penilaian meliputi indikator substansi, konstruksi, dan bahasa. Mekanisme penilaian sesuai permendiknas tersebut meliputi dua indikator yaitu perancangan strategi dan ulangan. Sementara itu, proses penilaian oleh pendidik pada pembelajaran sesuai ketentuan Permendiknas dimaksud meliputi sembilan kegiatan penilaian sebagai berikut.

- Menginformasikan silabus mata pelajaran yang di dalamnya memuat rancangan dan kriteria penilaian pada awal semester.

- Mengembangkan indikator pencapaian kompetensi dasar dan memilih teknik penilaian pada awal semester.

- Mengembangkan instrumen dan pedoman penilaian sesuai dengan bentuk dan teknik penilaian yang dipilih.

- Melaksanakan tes, pengamatan, penugasan, dan/atau bentuk lain yang diperlukan.

- Mengolah hasil penilaian untuk mengetahui kemajuan hasil belajar dan kesulitan belajar peserta didik.

- Mengembalikan hasil pemeriksaan pekerjaan peserta didik disertai balikan/komentar yang mendidik.

- Memanfaatkan hasil penilaian untuk perbaikan pembelajaran. 
- Melaporkan hasil penilaian mata pelajaran pada akhir setiap akhir semester kepada pimpinan satuan pendidikan dalam bentuk satu nilai prestasi belajar peserta didik disertai deskripsi singkat sebagai cerminan kompetensi utuh.

- Melaporkan hasil penilaian akhlak kepada guru pendidikan agama dan hasil penilaian kepribadian kepada guru pendidikan Kewarganegaraan sebagai informasi untuk menentukan nilai akhir semester akhlak dan kepribadian peserta didik dengan kategori sangat baik, baik, atau kurang baik. Peraturan tentang penilaian tersebut berlaku untuk semua mata pelajaran yang diajarkan di sekolah sesuai dengan kompetensi dasar masing-masing. Salah satunya adalah mata pelajaran geografi. Mata pelajaran ini diajarkan pada jenjang SMA kelas X, XI, dan XII.

Bantul merupakan salah satu kabupaten di Daerah Istimewa Yogyakarta yang telah mencoba menerapkan kebijakan kurikulum tahun 2006 dan proses penilaian sesuai Permendiknas Nomor 20 Tahun 2007 terhadap sekolah yang ada di daerah tersebut. Beberapa pandangan guru geografi yang dijumpai oleh penulis berkaitan dengan penilaian hasil belajar yang distandarkan secara nasional ditanggapi secara berbeda-beda. Salah satu pendapatnya menyatakan bahwa berbagai teknik/cara penilaian yang diatur secara nasional bagi guru termasuk guru geografi dirasakan lebih sulit dilaksanakan, karena berbeda dengan penilaian yang biasa mereka lakukan. Arahan dalam penilaian mengenai prinsip, teknik, instrumen, mekanisme, dan proses penilaian oleh pendidik dirasa lebih berat, karena kegiatan tersebut melalui proses yang relatif lama. Mereka menyatakan standar penilaian yang diatur oleh Permendiknas Nomor 20 Tahun 2007 idealnya dapat dilakukan oleh setiap satuan pendidikan dan guru mata pelajaran, tetapi ketentuan-ketentuan yang tertuang dalam standar penilaian tersebut seperti prinsip, teknik, mekanisme, instrumen dan proses penilaian dirasakan bagi sekolah masih sulit dilaksanakan. Menurut beberapa guru geografi yang dijumpai, kebiasaan yang selama ini berlangsung penilaian dilakukan dengan tes tertulis baik formatif maupun sumatif tanpa harus ada validasi soal dan teknik penilaian yang beragam. Oleh sebab itu, implementasi dari Permendiknas Nomor 20 Tahun 2007 ini memerlukan waktu dan masa transisi, merubah dari subjektifitas guru menjadi realitas kemampuan siswa. Para guru yang lain menyampaikan bahwa secara ilmiah sistem penilaian dalam peraturan tersebut lebih baik dalam mengukur keadaan siswa senyatanya karena sesuai dengan prosedur ilmiah, tetapi dalam praktiknya akan mengalami kendala dalam implementasinya

Berkaitan fenomena tersebut penulis tertarik untuk melakukan evaluasi terhadap implementasi Permendiknas Nomor 20 Tahun 2007 tentang Standar Penilaian Nasional. Evaluasi yang digunakan yaitu model Stake. Model Stake (Stake's countenance model of evaluation) menurut Kauffman \& Thomas (1980:123) dan Worthen \& Sanders, 1973:113) terkonsentrasi pada dua langkah pekerjaan evaluasi yaitu deskripsi 
dan pertimbangan serta membedakan adanya tiga tahap dalam evaluasi program yaitu: 1) input (antecedent); 2) proses (transaction); 3) hasil (outcomes). Secara garis besar penelitian ini ingin mengetahui apakah prinsip, teknik, instrumen, mekanisme dan proses penilaian oleh pendidik dalam pembelajaran geografi di Kabupaten Bantul Propinsi Daerah Istimewa Yogyakarta telah sesuai dengan Permendiknas tersebut.

\section{METODE}

Penelitian ini merupakan penelitian evaluasi dengan pendekatan deskriptif menggunakan model Stake. Model ini membandingkan antara proses penilaian yang berlangsung dalam pembelajaran geografi di lapangan dengan proses penilaian seharusnya sebagai kriteria untuk menentukan keberhasilan yaitu sesuai Peraturan Menteri Pendidikan Nasional Nomor 20 Tahun 2007. Pendekatan evaluasi model Stake menekankan adanya pelaksanaan dua hal pokok yaitu melakukan penggambaran (description) dan pertimbangan (judgments). Dua hal pokok ini diperoleh melalui gambaran tahapan evaluasi yaitu 1)input/pendahuluan(antecedent);2) proses (transaction); dan 3) hasil (out comes).

Populasi penelitian ini yaitu guru geografi SMA di Kabupaten Bantul kelas X, XI, dan XII. Pada penelitian ini responden yang dijadikan subjek diambil salah satu guru geografi pada setiap kelas secara acak sederhana (simple random) sehingga pada setiap sekolah diambil tiga orang guru. Pengambilan satu orang guru pada setiap kelas dengan pertimbangan bahwa setiap guru pada masing-masing kelas memiliki ke- samaan (homogen) pada kelasnya dalam pelaksanaan penilaian sesuai Permendiknas Nomor 20 Tahun 2007. Pada penelitian ini diambil 20 sekolah dari 38 sekolah yang mewakili 16 kecamatan di Bantul dan diperoleh sampel guru sebanyak 56 orang. Variabel dalam penelitian ini mengenai prinsip penilaian, teknik penilaian, dan instrumen penilaian, mekanisme penilaian, dan pelaksanaan penilaian oleh guru.

Teknik pengumpulan data yang digunakan disesuaikan dengan langkah dari evaluasi model Stake. Pada fase pendahuluan (Antecedent phase) akan digunakan teknik angket untuk memperoleh data pemahaman konsep pelaksanaan penilaian oleh guru yang sesuai Peraturan Menteri Pendidikan Nasional Nomor 20 Tahun 2007. Fase proses/ penerapan (Transaction phase) dideskripsikan pelaksanaan penilaian pembelajaran yang dilakukan oleh guru geografi melalui observasi. Fase terakhir, yaitu fase hasil program (Outcome phase) dilakukan pengukuran hasil pelaksanaan program pembelajaran yang diperoleh melalui data dari angket dan observasi.

Semua data yang dikumpulkan baik angket dan observasi dianalisis dengan menggunakan teknik analisis persentase kemudian dideskripsikan dan diambil kesimpulan tentang masing-masing komponen atas dasar kriteria yang telah ditentukan. Data variabel yang diperoleh dari hasil pengukuran dideskripsikan secara kuantitatif dan diklasifikasikan menjadi beberapa kategori sangat baik, baik, kurang baik, dan tidak baik. Berkenaan dengan keperluan tersebut digunakan skor rerata ideal (Mi) 
dan skor simpangan baku ideal (SBi) sebagai kriterianya. Tingkat kecenderungan dibagi dalam empat kategori yaitu:

$\begin{array}{ll}>(\mathrm{Mi}+1,5 \mathrm{SBi}) & : \text { sangat baik } \\ \mathrm{Mi}-(\mathrm{Mi}+1,5 \mathrm{SBi}) & : \text { baik } \\ (\mathrm{Mi}-1,5 \mathrm{SBi})-\mathrm{Mi} & : \text { kurang baik } \\ <(\mathrm{Mi}-1,5 \mathrm{SBi}) & : \text { tidak baik }\end{array}$

Penentuan jarak 1,5 SB untuk kategori ini dimaksudkan agar jarak kategori tidak terlalu kecil yang menjadikan kategori lebih banyak dan tidak terlalu lebar yang menjadikan kategori terlalu sedikit. Hal ini didasarkan pada distribusi normal yang terbagi enam bagian atau enam deviasi standar. Interval kategori variabel didasarkan pada skor tertinggi dan skor terendah dari masing masing variabel penelitian. Selanjutnya dicari skor rerata ideal (Mi) dan skor simpangan baku ideal (SBi) dengan menggunakan formula sebagai berikut: $\mathrm{Mi}=1 / 2$ (skor tertinggi + skor terendah) $\mathrm{SBi}=1 / 6$ (skor tertinggi - skor terendah).

Skor tertinggi ideal adalah skor tertinggi yang mungkin diperoleh subjek penelitian dari keseluruhan alternatif jawaban. Skor terendah ideal adalah skor terendah yang mungkin diperoleh subjek penelitian dari keseluruhan alternatif jawaban. Perhitungan skor tertinggi, terendah, Mi, dan Sbi. Berdasarkan kriteria di atas disusun standar skor kategori kecenderungan variabel dan indikator variabel penelitian yaitu dengan kategori sangat baik, baik, kurang baik, dan tidak baik.

\section{HASIL PENELITIAN}

\section{Fase Pendahuluan (Antecedent Phase)}

Pada tahapan ini dideskripsikan pemahaman konsep penilaian oleh guru SMA yang berkaitan dengan prinsip penilaian yang diperoleh melalui teknik angket. Hasil analisis mengenai variabel prinsip penilaian diperoleh rerata indikator pada interval $>58,5$ artinya termasuk kategori sangat baik. Distribusi frekuensi perolehan kategori skor variabel prinsip penilaian ditunjukkan oleh Tabel 1.

Tabel 1. Distribusi Frekuensi Perolehan Skor Variabel Prinsip Penilaian

\begin{tabular}{ccccc}
\hline No. & Interval & Kategori & Frekuensi & Frekuensi Relatif (\%) \\
\hline 1. & $>58,5$ & Sangat Baik & 50 & 89,28 \\
2. & $45-58,5$ & Baik & 6 & 10,72 \\
3. & $31,5-44,99$ & Kurang Baik & - & - \\
4. & $<31,5$ & Tidak Baik & - & - \\
& Jumlah & & 56 & 100 \\
\hline
\end{tabular}

Tabel 1 menunjukkan 89,28\% guruguru geografi di Kabupaten Bantul memiliki pemahaman dan kemampuan mengenai prinsip-prinsip penilaian dalam kategori sangat baik. Sebagian lainnya yaitu $10,72 \%$ dalam kategori baik. Hal ini menunjukkan bahwa secara umum guru-guru geografi SMA di Kabupaten Bantul kecenderungan memahami prinsip-prinsip penilaian sangat baik ditunjukkan oleh persentase terbesar perolehan skor tersebut. Sesuai Permendiknas Nomor 20 Tahun 2007 prinsip penilaian meliputi indikator ke- 
sahihan, objektif, adil, terpadu, terbuka, menyeluruh dan berkesinambungan, sistematis, beracuan kriteria, dan akuntabel.

\section{Fase Penerapan (Transaction Phase)}

Pada tahapan ini, dideskripsikan pelaksanaan penilaian yang dilakukan oleh guru geografi melalui observasi langsung dalam proses pembelajaran mengenai teknik, instrumen, mekanisme, dan proses penilaian oleh pendidik.

Berpedoman pada kategorisasi skor analisis data, rerata variabel teknik penilaian terletak pada interval 20-26 artinya termasuk kategori baik. Distribusi frekuensi perolehan kategori skor variabel teknik penilaian ditunjukkan oleh Tabel 2 berikut ini.

Tabel 2. Distribusi Frekuensi Perolehan Skor Variabel Prinsip Penilaian

\begin{tabular}{cllcc}
\hline No. & \multicolumn{1}{c}{ Interval } & \multicolumn{1}{c}{ Kategori } & Frekuensi & Frekuensi Relatif (\%) \\
\hline 1. & $>26$ & Sangat Baik & 18 & 32,14 \\
2. & $20-26$ & Baik & 38 & 67,85 \\
3. & $14-19,99$ & Kurang Baik & & - \\
4. & $<14 \quad$ & Tidak Baik & - & 100 \\
\hline
\end{tabular}

Guru-guru geografi di Kabupaten Bantul $67,85 \%$ memiliki pemahaman dan kemampuan dalam membuat teknik-teknik penilaian dalam kategori baik sisanya 32,14\% dalam kategori sangat baik. Data tersebut menggambarkan bahwa secara umum guru-guru geografi di Kabupaten Bantul dapat memahami dan melaksanakan teknik penilaian secara baik yang ditunjukkan oleh persentase terbesar perolehan skor tersebut. Sesuai Permendiknas nomor 20 tahun 2007 teknik penilaian meliputi indikator tes, observasi, penugasan, dan bentuk lain yang sesuai.

Hasil analisis untuk variabel instrumen penilaian rerata variabel ini terletak pada interval $>19,5$, artinya termasuk kategori sangat baik. Distribusi frekuensi perolehan kategori skor variabel teknik penilaian ditunjukkan oleh Tabel 3.

Tabel 3. Distribusi Frekuensi Perolehan Skor Variabel Instrumen Penilaian

\begin{tabular}{cllcc}
\hline No. & Interval & Kategori & Frekuensi & Frekuensi Relatif (\%) \\
1. & $>19,5$ & Sangat Baik & 45 & 80,3 \\
2. & $15-19,5$ & Baik & 11 & 19,7 \\
3. & $10,5-14,99$ & Kurang Baik & - & - \\
4. & $<10,5$ & Tidak Baik & - & - \\
& & Jumlah & 56 & 100 \\
\hline
\end{tabular}

Tabel 3 menginformasikan bahwa 80,3\% guru-guru geografi di Kabupaten
Bantul memiliki pemahaman dan kemampuan dalam membuat instrumen 
penilaian dalam kategori sangat baik dan sisa lainnya yaitu 19,7\% dalam kategori baik. Data tersebut menggambarkan bahwa secara umum guru-guru geografi di Kabupaten Bantul dapat memahami dan melaksanakan instrumen penilaian secara sangat baik yang ditunjukkan oleh persentase terbesar perolehan skor tersebut. Sesuai Permendiknas Nomor 20 Tahun 2007 instrumen penilaian meliputi indikator substansi, konstruksi, dan bahasa.
Hasil analisis diperoleh rerata variabel mekanisme penilaian terletak pada interval $>13$, artinya termasuk kategori sangat baik. Distribusi frekuensi perolehan kategori skor variabel mekanisme penilaian ditunjukkan oleh Tabel 4 . Sebagian besar guru-guru geografi (96,43\%) di Kabupaten Bantul memahami dan melaksanakan mekanisme penilaian dengan sangat baik sebagian lainnya 3,57\% dalam kategori baik.

Tabel 4. Distribusi Frekuensi Perolehan Skor Variabel Instrumen Penilaian

\begin{tabular}{ccccc}
\hline No. & Interval & Kategori & Frekuensi & Frekuensi Relatif (\%) \\
\hline 1. & $>13$ & Sangat Baik & 54 & 96,43 \\
2. & $10-13$ & Baik & 2 & 3,57 \\
3. & $7-9,99$ & Kurang Baik & - & - \\
4. & $<7$ & Tidak Baik & - & - \\
& & 56 & 100 \\
\hline
\end{tabular}

Data tersebut menggambarkan bahwa secara umum guru-guru geografi di Kabupaten Bantul dapat memahami dan melaksanakan mekanisme penilaian secara sangat baik yang ditunjukkan oleh persentase terbesar perolehan skor tersebut. Sesuai Permendiknas Nomor 20 Tahun 2007 mekanisme penilaian yang harus dilakukan guru mata pela- jaran meliputi 2 indikator yaitu perancangan strategi dan ulangan.

Hasil analisis variabel proses penilaian oleh guru geografi di Kabupaten Bantul diperoleh rerata pada interval $>58,5$ termasuk dalam kategori sangat baik. Distribusi frekuensi perolehan skor kecenderungan variabel pelaksanaan penilaian pembelajaran disajikan pada Tabel 5.

Tabel 5. Distribusi Frekuensi Perolehan Skor Kecenderungan Pelaksanaan Penilaian Pembelajaran

\begin{tabular}{ccccc}
\hline No. & Interval & Kategori & Frekuensi & Frekuensi Relatif $(\%)$ \\
\hline 1. & $>58,5$ & Sangat Baik & 47 & 83,93 \\
2. & $45-58,5$ & Baik & 9 & 16,07 \\
3. & $31,5-44,99$ & Kurang Baik & - & \\
4. & $<31,5$ & Tidak Baik & - & 100 \\
& Jumlah & & 56 & \\
\hline
\end{tabular}


Tabel 5 menunjukkan bahwa 83,93\% guru-guru geografi di Kabupaten Bantul memahami dan melaksanakan penilaian dengan sangat baik. Sebagian kecil lainnya yaitu $16,07 \%$ dalam kategori baik. Data tersebut menggambarkan bahwa secara umum guru-guru geografi di Kabupaten Bantul dapat telah melaksanakan proses penilaian oleh pendidik secara sangat baik yang ditunjukkan oleh persentase terbesar perolehan skor tersebut. Sesuai Permendiknas Nomor 20 Tahun 2007 pelaksanaan penilaian mliputi sembilan kegiatan.

\section{Fase Hasil Program (Outcome Phase)}

Pada fase ini dilakukan pengukuran hasil pelaksanaan evaluasi pada dua fase sebelumnya, yaitu berhubungan dengan prinsip, teknik, instrumen, dan mekanisme serta proses penilaian yang telah dilakukan oleh guru. Hasil analisis statistik, pengukuran hasil evaluasi penilaian pembelajaran geografi SMA di Kabupaten Bantul memiliki rerata sebesar 187,75. Artinya, kemampuan penilaian pembelajaran geografi dalam kategori sangat baik, Distribusi frekuensi perolehan skor pada variabel ini disajikan pada Tabel 6 .

Tabel 6. Distribusi Frekuensi Perolehan Skor Kecenderungan Pelaksanaan Penilaian Pembelajaran Geografi

\begin{tabular}{ccccc}
\hline No. & Interval & Kategori & Frekuensi & Frekuensi Relatif (\%) \\
\hline 1. & $>175,5$ & Sangat Baik & 47 & 83,93 \\
2. & $135-175,5$ & Baik & 9 & 16,07 \\
3. & $94,5-134,99$ & Kurang Baik & - & - \\
4. & $<94,5$ & Tidak Baik & - & - \\
& Jumlah & & 48 & 100 \\
\hline
\end{tabular}

Hasil analisis pada fase ini dijadikan peneliti sebagai dasar pertimbangan (judgment) pelaksanaan penilaian pembelajaran geografi SMA di Kabupaten Bantul. Berdasarkan standar ideal (absolute standard) yang ditunjukkan oleh kategorisasi hasil analisis sebagai realisasi di lapangan dan standar relatif (relative standard) yaitu mendasarkan standar yang diinginkan Permendiknas Nomor 20 Tahun 2007, maka diantara kedua standar tersebut terdapat kesesuaian (congruence) antara yang diharapkan (intended) dengan yang diamati (observed).

\section{PEMBAHASAN}

Hasil penelitian yang mendukung pelaksanaan penilaian oleh guru sesuai Peraturan Menteri Pendidikan Nasional Nomor 20 Tahun 2007, yaitu berkaitan dengan prinsip, teknik, instrumen, dan mekansime atau prosedur penilaian serta pelaksanaannya diperoleh data bahwa sebagian besar guru geografi sudah menerapkan peraturan tersebut. Hal ini terungkap dari hasil analisis distribusi skor kategori total penilaian yaitu, sebesar $83,93 \%$ dari 56 responden guru geografi sudah melaksanakan penilaian sesuai permendiknas nomor 
20 tahun 2007 dengan kategori sangat baik dan sisanya dikelompokkan dalam kategori baik (16,07\%). Hasil ini setidaknya memberikan gambaran pelaksanan penilaian untuk guru geografi se-Kabupaten Bantul yang berjumlah sekitar 90 guru yang tersebar ke dalam 21 SMA Negeri dan 17 SMA swasta. Sampel yang digunakan diperoleh dari 16 kecamatan yang diwakili oleh setidaknya masing-masing satu sekolah SMA swasta dan Negeri.

Prinsip-prinsip penilaian sesuai Permendiknas Nomor 20 Tahun 2007 yang dilakukan guru-guru geografi di Kabupaten Bantul dapat dilihat dari deskripsi data pada bagian sebelumnya yang menempatkan secara umum guru-guru geografi SMA di Kabupaten Bantul kecenderungan memahami dan melaksanakan prinsip-prinp penilaian sangat baik. Sesuai Permendiknas Nomor 20 Tahun 2007 prinsip penilaian meliputi indikator kesahihan, objektif, adil, terpadu, terbuka, menyeluruh dan berkesinambungan, sistematis, beracuan kriteria, dan akuntabel. Keshahihan penilaian didasarkan pada data yang mencerminkan kemampuan yang diukur. Objektifitas didasarkan pada prosedur dan kriteria yang jelas, tidak dipengaruhi subjektivitas penilai. Prinsip keadilan tidak menguntungkan atau merugikan peserta didik karena berkebutuhan khusus serta perbedaan latar belakang agama suku, budaya, adat istiadat, status sosial ekonomi, dan gender. Keterpaduan penilaian yaitu tak terpisahkan dari kegiatan pembelajaran. Keterbukaan ditunjukkan olehg prosedur penilaian, kriteria penilaian, dan dasar pengambilan keputusan dapat di- ketahui oleh pihak yang berkepentingan. Menyeluruh dan berkesinambungan artinya penilaian oleh pendidik mencakup semua aspek kompetensi dengan menggunakan berbagai teknik penilaian yang sesuai, untuk memantau perkembangan kemampuan peserta didik. Sistematis merupakan prinsip penilaian yang dilakukan secara berencana dan bertahap dengan mengikuti langkahlangkah baku. Beracuan kriteria yaitu penilaian didasarkan pada ukuran pencapaian kompetensi yang ditetapkan, dan terakhir akuntabel yaitu penilaian dapat dipertanggungjawabkan, baik dari segi teknik, prosedur, maupun hasilnya.

Data hasil penelitian berkaitan dengan teknik penilaian menggambarkan bahwa secara umum guru-guru geografi di Kabupaten Bantul dapat memahami dan melaksanakan teknik penilaian secara baik yang ditunjukkan oleh persentase terbesar perolehan skor tersebut. Sesuai Permendiknas Nomor 20 Tahun 2007 teknik penilaian meliputi indikator tes, observasi, penugasan, dan bentuk lain. Penilaian hasil belajar oleh guru geografi menggunakan berbagai teknik penilaian berupa tes, observasi, penugasan perseorangan atau kelompok, dan bentuk lain yang sesuai dengan karakteristik kompetensi dan tingkat perkembangan peserta didik. Hasil analisis menunjukkan bahwa teknik penilaian yang paling banyak digunakan dalam pembelajaran geografi berupa tes dengan pemahaman yang sangat baik, diikuti oleh penugasan, bentuk-bentuk lain dan observasi.

Berkaitan dengan instrumen penilaian yang dibuat oleh guru geografi 
SMA di Kabupaten Bantul digambarkan bahwa secara umum guru-guru geografi di Kabupaten Bantul dapat memahami dan melaksanakan instrumen penilaian dengan sangat baik yang ditunjukkan oleh persentase terbesar perolehan skor tersebut. Sesuai Permendiknas Nomor 20 Tahun 2007 instrumen penilaian meliputi indikator substansi, konstruksi, dan bahasa. Substansi adalah merepresentasikan kompetensi yang dinilai. Konstruksi adalah memenuhi persyaratan teknis sesuai dengan bentuk instrumen yang digunakan, dan bahasa yaitu menggunakan bahasa yang baik dan benar serta komunikatif sesuai dengan taraf perkembangan peserta didik.

Mekanisme penilaian oleh guruguru geografi dalam penilaian dilakukan secara sangat baik yang ditunjukkan oleh persentase terbesar perolehan skor tersebut. Sesuai Permendiknas Nomor 20 Tahun 2007 mekanisme penilaian yang harus dilakukan guru mata pelajaran meliputi 2 indikator yaitu perancangan strategi dan ulangan. Perancangan strategi penilaian oleh pendidik dilakukan pada saat penyusunan silabus yang penjabarannya merupakan bagian dari rencana pelaksanaan pembelajaran (RPP). Ulangan tengah semester, ulangan akhir semester, dan ulangan kenaikan kelas dilakukan oleh pendidik di bawah koordinasi satuan pendidikan

Hasil analisis statistik variabel proses penilaian oleh pendidik menunjukkan bahwa guru-guru geografi di Kabupaten Bantul memahami dan melaksanakan penilaian dengan sangat baik dan baik. Sesuai Permendiknas Nomor
20 Tahun 2007 pelaksanaan penilaian meliputi sembilan kegiatan.

- Sebagian besar guru geografi selalu menginformasikan silabus mata pelajaran yang di dalamnya memuat kriteria penilaian pada setiap awal semester.

- Kegiatan mengembangkan indikator pencapaian kompetensi dasar dan memilih teknik penilaian pada awal semester telah sangat baik dilakukan.

- Mengembangkan instrumen dan pedoman penilaian sesuai dengan bentuk dan teknik penilaian yang dipilih digambarkan bahwa sebagian besar guru selalu melaksanakan kegiatan indikator tersebut telah sangat baik.

- Hasil penelitian menggambarkan bahwa sebagian besar guru selalu melaksanakan kegiatan indikator melaksanakan tes, pengamatan, penugasan, dan/atau bentuk lain yang diperlukantersebut dengan sangat baik.

- Sebagian besar guru selalu mengolah hasil penilaian untuk mengetahui kemajuan hasil belajar dan kesulitan belajar peserta didik. Artinya, guru selalu melakukan monitoring (kontrol) terhadap prestasi siswa dan ketuntasan belajar siswa.

- Mengembalikan hasil pemeriksaan pekerjaan peserta didik disertai balikan komentar yang mendidik dilaksanakan oleh sebagian besar dengan kategori sangat baik. Hal ini menunjukkan adanya kegiatan penilaian dan dokumentasi prestasi siswa secara berkesinambungan sehingga prestasi siswa dapat dicermati dari waktu ke waktu. Setiap siswa dapat melakukan pengamatan secara pribadi atas hasil pembelajarannya dari 
hasil pengolahan nilai yang dilakukan oleh guru.

- Memanfaatkan hasil penilaian untuk perbaikan pembelajaran dilaksanakan oleh sebagian besar guru geografi dengan kategori sangat baik. Artinya, perbaikan pembelajaran geografi selalu diupayakan lebih baik melalui hasil evaluasi yang diperoleh dari penilaian yang dilakukan.

- Kegiatan melaporkan hasil penilaian mata pelajaran pada akhir setiap akhir semester kepada pimpinan satuan pendidikan dalam bentuk satu nilai prestasi belajar peserta didik disertai deskripsi singkat sebagai cerminan kompetensi utuh sudah dilakukan oleh sebagian besar guru. Artinya guru melaporkan dokumen penilaian secara utuh kepada pimpinan dalam hal ini kepala sekolah sebagai laporan pembelajaran siswa yang diajarnya. Laporan yang dimaksud berupa nilai akhir yang diperoleh siswa beserta status siswa tersebut dalam pembelajaran kategori siswa baik, kurang baik, atau perlu penangan khusus. Pada akhirnya, laporan guru bersangkutan akan dijadikan dasar kebijakan pimpinan dalam mengevaluasi pembelajaran yang berlangsung di satuan pendidikan bersangkutan.

- Kegiatan melaporkan hasil penilaian akhlak kepada guru pendidikan agama dan hasil penilaian kepribadian kepada guru pendidikan Kewarganegaraan sebagai informasi untuk menentukan nilai akhir semester akhlak dan kepribadian peserta didik dengan kategori sangat baik, baik, atau kurang baik sudah dilakukan Lapor- an yang dimaksud berupa nilai akhir yang diperoleh siswa beserta status siswa tersebut dalam pembelajaran yaitu siswa masuk kategori sangat baik, baik, atau kurang baik. Laporan guru mata pelajaran akan dijadikan dasar kebijakan dalam menentukan nilai akhlak dan kepribadian siswa selama satu semester.

\section{KESIMPULAN}

- Guru geografi SMA di Kabupaten Bantul memahami prinsip-prinsip penilaian secara sangat baik ditunjukkan oleh persentase terbesar perolehan skor tersebut $(89,28 \%)$.

- Pelaksanaan penilaian pembelajaran geografi SMA di Kabupaten Bantul berkaitan dengan teknik penilaian dilaksanakan secara baik $(67,85 \%)$, sementara instrumen (80,3\%), mekanisme $(96,43 \%)$ dan proses penilaian oleh pendidik $(83,93 \%)$ dalam kategori sangat baik. Hal ini ditunjukkan oleh persentase terbesar dari masingmasing indikator

- Hasil analisis statistik, pengukuran hasil evaluasi penilaian pembelajaran geografi SMA di Kabupaten Bantul dalam kategori sangat baik $(83,93 \%)$. Berdasarkan standar ideal (absolute standard) yang ditunjukkan oleh kategorisasi hasil analisis sebagai realisasi di lapangan dan standar relatif (relative standard) yaitu mendasarkan standar yang diinginkan Permendiknas Nomor 20 Tahun 2007, maka di antara kedua standar tersebut terdapat kesesuaian (congruence) antara yang diharapkan (intended) dengan yang diamati (observed). 


\section{UCAPAN TERIMA KASIH}

Penelitian ini tidak lepas dari bantuan berbagai pihak secara moril, tenaga, waktu maupun materil. Kami mengucapkan terimakasih kepada:

- Universitas Negeri Yogyakarta, terutama Lembaga Penelitian yang telah memberikan kesempatan bagi peneliti untuk melaksanakan penelitian.

- Pemerintah Propinsi D.I. Yogyakarta, terutama Pemerintah Daerah Kabupaten Bantul atas izin yang telah diberikan.

- Redaktur dan reviewer Jurnal Cakrawala Pendidikan yang telah memuat hasil penelitian ini.

- Semua pihak yang telah terlibat dalam penelitian ini.

\section{DAFTAR PUSTAKA}

Arikunto, Suharsimi. 2001. Prosedur Penelitian Suatu Pendekatan Praktek. Jakarta: Rineka Cipta.

Brinkerhoff, R. D., Brethower, D. M. Hluchyj, T., et al. 1983. Program Evaluasion a Practitioner's Guide for Traners and Educator. Western Michigan:Klower-nijhoff Publishing.

BSNP. 2006. Panduan Penyusunan Kurikulum Tingkat Satuan Pendidikan Jenjang Pendidikan Dasar dan Menengah. Jakarta.

Depdiknas. 2003. Undang-Undang Nomor 20 Tahun 2003 tentang Sistem Pendidikan Nasional. Jakarta: Sekretariat Negara.
Depdiknas. 2005. Peraturan Pemerintah. No 19 Tahun 2005 tentang Standar Nasional Pendidikan. Jakarta: Sekretariat Negara.

Depdiknas. 2007. Peraturan Menteri Pendidikan Nasional Nomor 20 Tahun 2007. Jakarta.

Ebel. Robert L. 1979. Essentials of Educational Measurement (Third Edition). New Jersey: Prentice Hall.

Kaufman. R. \& Susan Thomas. 1980. Evaluation Without Fear. New York: New View Point.

Stufflebeam, D.L. \& Shinkfield, A.J. 1985. Systematic Evaluation: A Intuctional Guide to Theory $\mathcal{E}$ Practice. Boston: Klower-nijhoff Publishing.

Weiss. Carol H. 1972. Evaluation Research. Englewoods Cliffs: Prentice Hall.

Worthen R. Blaine \& Sanders R.J. 1981. Educational Evaluation: Theory and Practice. California: Wadsworth Publishing Company. Inc. 